\title{
Maxillary Mucormycosis Osteomyelitis in Post COVID-19 Patients: A Series of Fourteen Cases
}

\author{
Wael M. Said Ahmed ${ }^{1}$, Amira M. Elsherbini ${ }^{2, *}$, Nehal M. Elsherbiny ${ }^{3,4} \mathbb{C}^{\circ}$, Mohamed El-Sherbiny $5,6, * \mathbb{0}$, \\ Nevine I. Ramzy ${ }^{7}$ and Ahmed F. Arafa ${ }^{8}$
}

1 Oral and Maxillofacial Department, Faculty of Dentistry, Mansoura University, Mansoura 35516, Egypt; drwaelmohamed2020@gmail.com

2 Oral Biology Department, Faculty of Dentistry, Mansoura University, Mansoura 35516, Egypt

3 Department of Biochemistry, Faculty of Pharmacy, Mansoura University, Mansoura 35516, Egypt; drnehal@mans.edu.eg

4 Department of Pharmaceutical Chemistry, Faculty of Pharmacy, University of Tabuk, Tabuk 47512, Saudi Arabia

5 Department of Basic Medical Sciences, College of Medicine, AlMaarefa University, Riyadh 71666, Saudi Arabia

6 Department of Anatomy, Mansoura Faculty of Medicine, Mansoura University, Mansoura 35516, Egypt

7 Pathology Department, Faculty of Medicine, Cairo University, Giza 11562, Egypt; ramzywebas@gmail.com

8 Oral and Maxillofacial Department, Zagazig University, Zagazig 44519, Egypt; arafabelal@gmail.com

* Correspondence: amiraelsherbini@mans.edu.eg (A.M.E.); msharbini@mcst.edu.sa (M.E.-S.)

Citation: Said Ahmed, W.M.;

Elsherbini, A.M.; Elsherbiny, N.M.; El-Sherbiny, M.; Ramzy, N.I.; Arafa, A.F. Maxillary Mucormycosis Osteomyelitis in Post COVID-19 Patients: A Series of Fourteen Cases. Diagnostics 2021, 11, 2050. https:// doi.org/10.3390/diagnostics11112050

Academic Editor: Alessandro Russo

Received: 20 October 2021

Accepted: 3 November 2021

Published: 5 November 2021

Publisher's Note: MDPI stays neutral with regard to jurisdictional claims in published maps and institutional affiliations.

Copyright: (C) 2021 by the authors. Licensee MDPI, Basel, Switzerland. This article is an open access article distributed under the terms and conditions of the Creative Commons Attribution (CC BY) license (https:/ / creativecommons.org/licenses/by/ $4.0 /)$.

\begin{abstract}
During the current pandemic of COVID-19, numerous manifestations and complications have developed. Patients with COVID-19 are at high risk of fungal infections, such as mucormycosis, that may result directly from COVID-19 infection and/or as a side effect of the drugs used in COVID-19 treatment protocol, such as dexamethasone, hydroxychloroquine, and antibiotics. In this report, we described a series of 14 cases with maxillary mucormycosis osteomyelitis in immediate post-COVID-19 patients.
\end{abstract}

Keywords: COVID-19; mucormycosis; maxilla; osteomyelitis

\section{Introduction}

Coronavirus disease 2019 (COVID-19 \& COVID) is a contagious pandemic disease caused by severe acute respiratory syndrome coronavirus2 (SARS-CoV-2). COVID-19 has variable signs and symptoms, but often include fever, cough, headache, hypoxia, thromboembolic disorders, fatigue, dyspnea, diarrhea, anosmia, and ageusia [1]. About 1/3 of infected people are asymptomatic. In symptomatic patients, $81 \%$ have mild to moderate symptoms, while $14 \%$ develop severe symptoms and $5 \%$ suffer critical symptoms [2]. Immunocompromised and old people are at a greater risk of developing severe symptoms. Symptoms may occur 1-14 days' post COVID-19 exposure and some patients continue to experience a variety of effects for months after recovery (long COVID) [3].

Osteomyelitis is an inflammatory condition affecting the bone that usually begins from the medullary spaces, rapidly involving the Haversian systems, and extending to periosteum of the involved area. Inflammation and edema that result from the infection compromise the blood supply leading to bone ischemia, which in sequence becomes necrotic [4].

Mucormycosis is an angio-invasive fungal infection caused by fungi in the order Mucorales and usually begins in the nose and para-nasal sinuses. Infection may result from inhalation, ingestion, or contamination of ulcerated mucosa or skin by fungal spores. It is rapidly progressing and potentially destructive and life-threatening in immunocompromised, debilitating, or diabetic individuals $[5,6]$. 


\section{Case Series}

This case series included 14 patients and followed the Declaration of Helsinki guidelines, also it was approved by Ethical Committee of Faculty of Dentistry, Mansoura University. An informed consent was signed from each patient. All the patients had recent COVID-19 infection and were quarantined for 20-30 days; four patients in home, seven patients in hospital ward, and three patients in ICU. The patients attended Oral and Maxillofacial Surgery Departments in Zagazig University and Faculty of Dentistry of Mansoura University, Egypt, 14-30 days' post COVID-19 recovery, complaining from pain, loss of one or more maxillary teeth, exposed bone, pus discharge, and bad odor. Clinical and radiographic examination were shown in Table 1 and Figures 1-5. Swab for culture and incisional biopsy were taken from each patient.

Table 1. Personal data, clinical presentation, radiological features, and treatment for cases series.

\begin{tabular}{|c|c|c|c|c|c|c|}
\hline $\begin{array}{l}\text { Case } \\
\text { No. }\end{array}$ & $\begin{array}{c}\text { Age/ } \\
\text { Gender }\end{array}$ & $\begin{array}{l}\text { Medical } \\
\text { Status }\end{array}$ & Site & $\begin{array}{c}\text { Clinical } \\
\text { Presentation }\end{array}$ & $\begin{array}{l}\text { Radiographic } \\
\text { Features(CT) }\end{array}$ & Treatment * \\
\hline 1 & $\begin{array}{l}45 / \\
\text { Male }\end{array}$ & $\begin{array}{l}\text { Post-COVID- } \\
\text { diabetes }\end{array}$ & $\begin{array}{l}\text { Alveolar bone } \\
+ \text { palatal bone } \\
\text { anterior region }\end{array}$ & $\begin{array}{l}\text { palatal bone } \\
\text { exposure, teeth } \\
\text { loosening }\end{array}$ & $\begin{array}{l}\text { Palatal and alveolar } \\
\text { bone rarefaction }\end{array}$ & $\begin{array}{l}\text { Debridement and } \\
\text { curettage }\end{array}$ \\
\hline 2 & $\begin{array}{c}35 / \\
\text { Male }\end{array}$ & $\begin{array}{l}\text { Post-COVID- } \\
\text { diabetes }\end{array}$ & $\begin{array}{l}\text { Right posterior } \\
\text { palatal bone }\end{array}$ & $\begin{array}{l}\text { ENB, extraoral } \\
\text { pus discharge }\end{array}$ & $\begin{array}{l}\text { BD involving right } \\
\text { maxilla, inferior orbital } \\
\text { rim, lower part of } \\
\text { zygoma }\end{array}$ & $\begin{array}{l}\text { Right total } \\
\text { maxillectomy without } \\
\text { orbital excenteration }+ \\
\text { resection of involved } \\
\text { part of zygoma }\end{array}$ \\
\hline 3 & $\begin{array}{c}65 / \\
\text { Male }\end{array}$ & Diabetic & $\begin{array}{c}\text { Bilateral } \\
\text { palatal + } \\
\text { alveolar bone }\end{array}$ & ENB, PP & $\begin{array}{l}\text { BD involving right and } \\
\text { left maxillae (not } \\
\text { involve inferior orbital } \\
\text { rims) + left pterygoid } \\
\text { plates }\end{array}$ & $\begin{array}{l}\text { Bilateral subtotal } \\
\text { maxillectomy }+ \\
\text { removal of left } \\
\text { pterygoid plates }\end{array}$ \\
\hline 4 & $\begin{array}{c}48 / \\
\text { Male }\end{array}$ & Diabetic & $\begin{array}{c}\text { Bilateral } \\
\text { palatal + } \\
\text { alveolar bone }\end{array}$ & ENB, PP & $\begin{array}{l}\text { BD involving right and } \\
\text { left maxillae (not } \\
\text { involve inferior orbital } \\
\text { rims) }\end{array}$ & $\begin{array}{l}\text { Bilateral subtotal } \\
\text { maxillectomy }\end{array}$ \\
\hline 5 & $\begin{array}{c}76 / \\
\text { Male }\end{array}$ & Diabetic & $\begin{array}{l}\text { Right side of } \\
\text { the palate }+ \\
\text { alveolar bone }\end{array}$ & $\begin{array}{l}\text { ENB, PP, loss of } \\
\text { vision }\end{array}$ & $\begin{array}{l}\text { BD involving right } \\
\text { maxilla and orbit }\end{array}$ & $\begin{array}{c}\text { Right total } \\
\text { maxillectomy with } \\
\text { orbital excenteration }\end{array}$ \\
\hline 6 & $\begin{array}{c}55 / \\
\text { Female }\end{array}$ & Diabetic & $\begin{array}{l}\text { left side of the } \\
\text { palate }\end{array}$ & ENB, PP & $\begin{array}{l}\text { BD involving left } \\
\text { maxilla }\end{array}$ & $\begin{array}{l}\text { left subtotal } \\
\text { maxillectomy }\end{array}$ \\
\hline 7 & $\begin{array}{c}61 / \\
\text { Female }\end{array}$ & Diabetic & $\begin{array}{l}\text { Left side of the } \\
\text { Palate }+ \\
\text { Alveolar bone }\end{array}$ & ENB, loss of vision & $\begin{array}{c}\text { BD involving left } \\
\text { maxilla and lower part } \\
\text { of zygoma }\end{array}$ & $\begin{array}{c}\text { Left subtotal } \\
\text { maxillectomy }+ \\
\text { resection of involved } \\
\text { part of zygoma }\end{array}$ \\
\hline 8 & $\begin{array}{c}45 / \\
\text { Male }\end{array}$ & $\begin{array}{l}\text { Post-COVID- } \\
\text { diabetes }\end{array}$ & $\begin{array}{l}\text { Alveolar bone } \\
\text { Anteriorly }+ \\
\text { palatal bone } \\
\text { anterior region }\end{array}$ & $\begin{array}{l}\text { palatal bone } \\
\text { exposure, teeth } \\
\text { loosening }\end{array}$ & $\begin{array}{l}\text { Palatal and alveolar } \\
\text { Bone Rarefaction }\end{array}$ & $\begin{array}{l}\text { Debridement and } \\
\text { curettage }\end{array}$ \\
\hline 9 & $\begin{array}{c}52 / \\
\text { Male }\end{array}$ & Diabetic & $\begin{array}{l}\text { Anterior third } \\
\text { Of the palate }\end{array}$ & $\begin{array}{l}\text { palatal bone } \\
\text { exposure + PP }\end{array}$ & $\begin{array}{l}\text { Palatal and alveolar } \\
\text { Bone rarefaction+ ONC }\end{array}$ & Partial maxillectomy \\
\hline 10 & $\begin{array}{c}53 / \\
\text { Female }\end{array}$ & Diabetic & $\begin{array}{c}\text { Anterior third } \\
\text { of the palate }+ \\
\text { alveolar } \\
\text { process of } \\
\text { anterior teeth }\end{array}$ & $\begin{array}{l}\text { Necrosis of of } \\
\text { premaxilla }+ \text { PP }\end{array}$ & $\begin{array}{l}\text { BD of premaxilla }+ \\
\text { ONC }\end{array}$ & Partial maxillectomy \\
\hline
\end{tabular}


Table 1. Cont.

\begin{tabular}{|c|c|c|c|c|c|c|}
\hline $\begin{array}{l}\text { Case } \\
\text { No. }\end{array}$ & $\begin{array}{c}\text { Age/ } \\
\text { Gender }\end{array}$ & $\begin{array}{l}\text { Medical } \\
\text { Status }\end{array}$ & Site & $\begin{array}{c}\text { Clinical } \\
\text { Presentation }\end{array}$ & $\begin{array}{l}\text { Radiographic } \\
\text { Features(CT) }\end{array}$ & Treatment * \\
\hline 11 & $29 / \mathrm{M}$ & $\begin{array}{c}\text { Post-COVID-19 } \\
\text { diabetes }\end{array}$ & $\begin{array}{c}\text { Premaxilla }+ \\
\text { left } \\
\text { palate }\end{array}$ & $\begin{array}{l}\text { ENB of premaxilla } \\
\text { and Left palate } \\
\text { with alveolar } \\
\text { processes }\end{array}$ & $\begin{array}{c}\text { BD involving } \\
\text { Premailla+ left maxilla } \\
\text { (not involve inferior } \\
\text { orbital rims) }\end{array}$ & $\begin{array}{l}\text { Left subtotal } \\
\text { maxillectomy }\end{array}$ \\
\hline 12 & $77 / \mathrm{M}$ & Diabetic & $\begin{array}{c}\text { Bilateral } \\
\text { palatal }+ \\
\text { alveolar bone }\end{array}$ & ENB and PP & $\begin{array}{l}\text { BD involving right and } \\
\text { left maxillae (not } \\
\text { involve inferior orbital } \\
\text { rims) }\end{array}$ & $\begin{array}{l}\text { Bilateral subtotal } \\
\text { maxillectomy }\end{array}$ \\
\hline 13 & $49 / F$ & $\begin{array}{c}\text { Post-COVID-19 } \\
\text { diabetes }\end{array}$ & $\begin{array}{l}\text { Anterior and } \\
\text { right part of } \\
\text { the palate }+ \\
\text { alveolar bone }\end{array}$ & ENB and PP & $\begin{array}{c}\text { BD involving } \\
\text { Premaxilla + ONC+ } \\
\text { right maxilla with } \\
\text { pterygoid plates (not } \\
\text { involve inferior Orbital } \\
\text { rim) }\end{array}$ & $\begin{array}{l}\text { Right subtotal } \\
\text { maxillectomy+ } \\
\text { removal of right } \\
\text { pterygoid plates }\end{array}$ \\
\hline 14 & $69 / \mathrm{M}$ & Diabetic & $\begin{array}{c}\text { Right side of } \\
\text { the } \\
\text { Palate }\end{array}$ & ENB and PP & $\begin{array}{l}\text { BD involving right } \\
\text { maxilla (not involve } \\
\text { inferior Orbital rims) }\end{array}$ & $\begin{array}{l}\text { Right subtotal } \\
\text { maxillectomy }\end{array}$ \\
\hline
\end{tabular}

Post-COVID-19-diabetes (patients were nondiabetic then became diabetic Post-COVID), Exposed necrotic bone (ENB), Bone destruction (BD), Palatal perforation (PP), oronasal communication (ONC). * According to Cordeiro's [7] maxillectomy classification: Type I, Partial

1-2 maxillary walls; Type II, Subtotal of three to five maxillary walls including the palate; Type III, Total Involves all six maxillary walls:

(a) Lacking orbital exenteration, (b) With orbital exenteration; Type IV, Radical includes five maxillary walls, palate and orbit excepted.
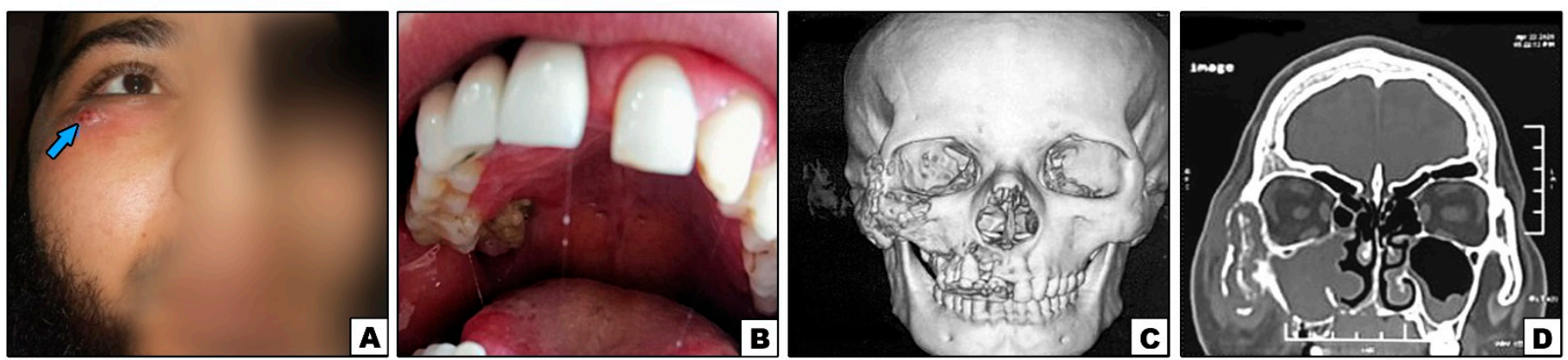

Figure 1. Case\#2: (A) Extraoral swelling of the right side of the face (note: sinus tract inferolaterally to the eye \{arrow\}). (B) Exposed necrotic bone in the right posterior palate. (C,D) 3D and cronal CT showing bone destruction of right maxilla, inferior orbital rim, and lower part of zygoma.
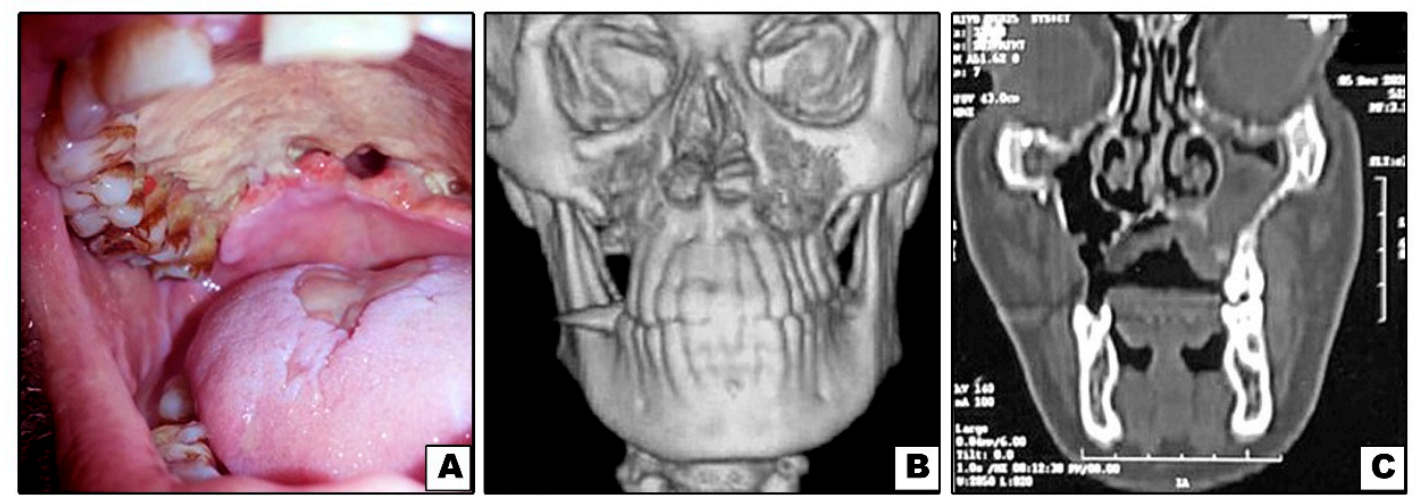

Figure 2. Case\#3: (A) Exposed necrotic palatal bone with palatal perforations. (B,C) 3D and coronal CT showing bone destruction of right and left maxillae (not involving inferior orbital rims). 

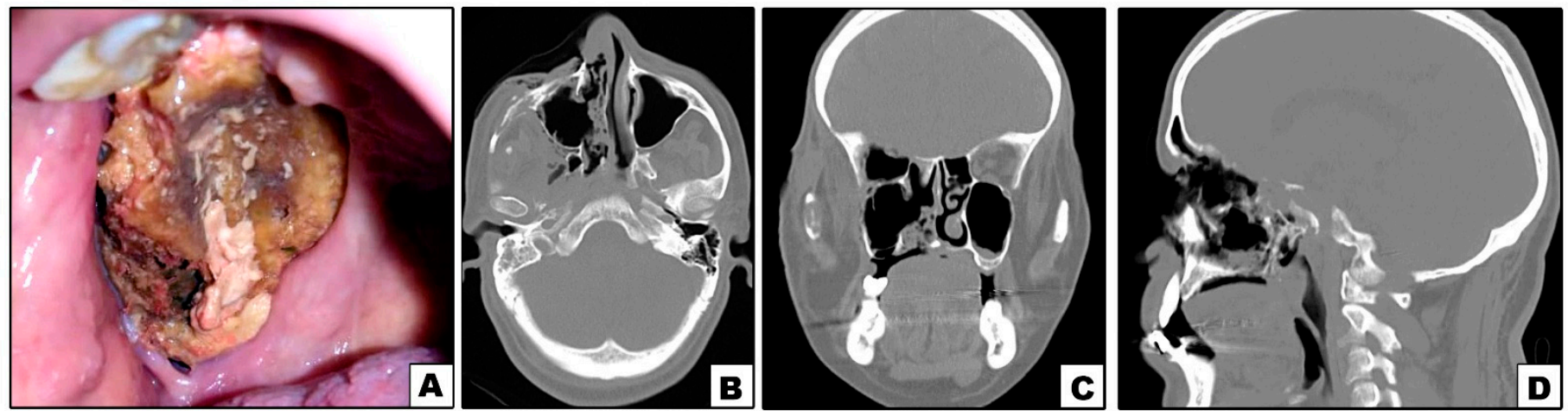

Figure 3. Case\#5: (A) Exposed necrotic palatal and alveolar bone on right side. (B-D) Axial, coronal and sagittal CT showing bone destruction involving right maxilla and orbit.
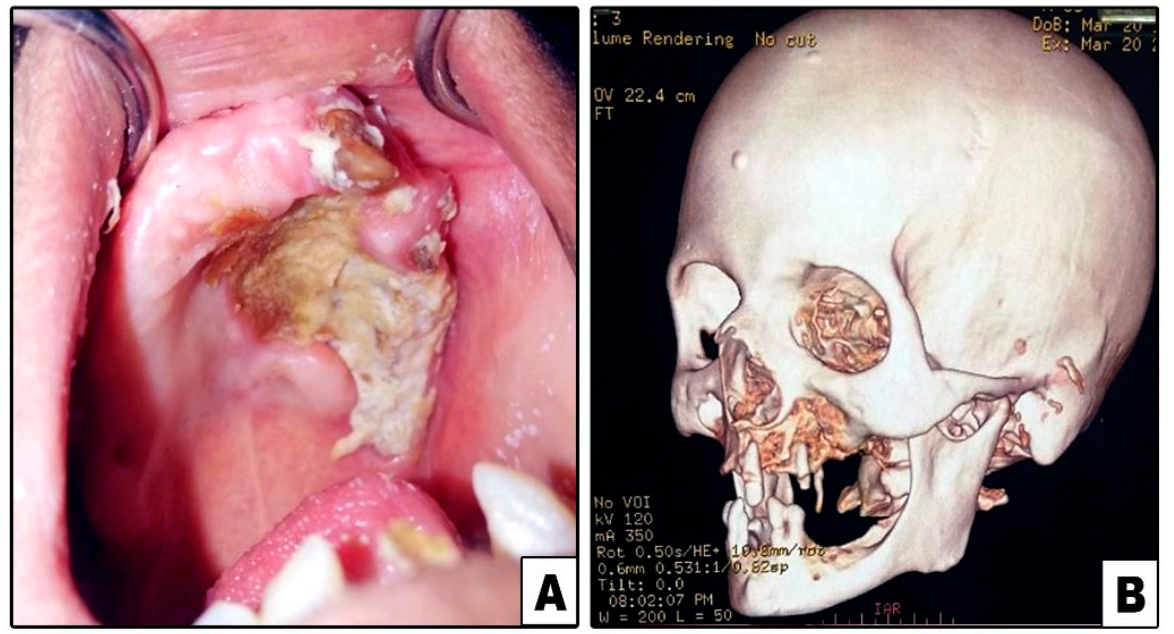

Figure 4. Case\#7: (A) Exposed necrotic palatal and alveolar bone on left side. (B) 3D CT showing bone destruction involving left maxilla and lower part of zygoma.
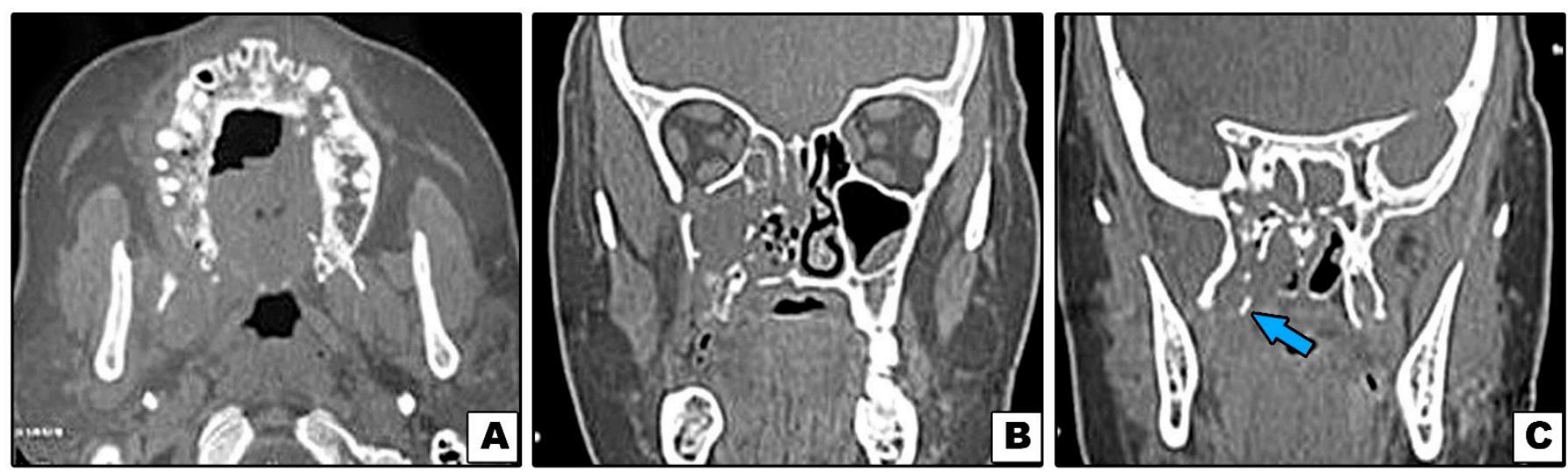

Figure 5. Case\#13: (A-C) Axial and coronal CT showing bone destruction involving premaxilla, right maxilla with pterygoid plates (arrow), and not involving inferior orbital rim.

Histopathological picture (Figure 6) revealed an invasive mucormycosis showing collections of nonseptate hyphae with right angle branching and spores of mucormycosis surrounded by necrotic tissues and a dense inflammatory infiltration. 

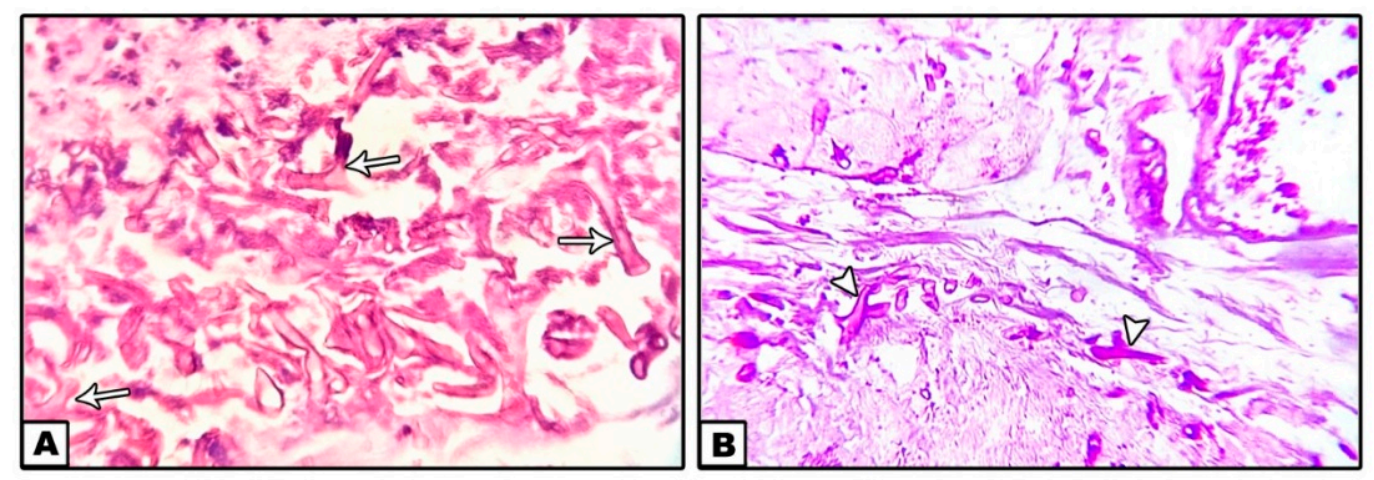

Figure 6. Nonseptate hyphae with right angle branching (arrows) and spores of mucormycosis surrounded by necrotic tissues and a dense inflammatory infiltration. $((\mathbf{A}): \mathrm{H} \& \mathrm{E} \times 40,(\mathbf{B}):$ PAS $\times 40)$.

All the patients received $150 \mathrm{mg} / 3$ days of Fluconazole antifungal drug (Diflucan, Pfizer, Brooklyn, NY, USA) for 1 month, and 30 dives of hyperbaric oxygen ( $0.5 \mathrm{~h} /$ day). After that, the patients had surgical treatment varying from debridement and curettage to extensive bone removal according to the degree of bone involvement in each case. (Table 1) After surgery, all patients received 20 dives of hyperbaric oxygen $(0.5 \mathrm{~h} /$ day), and $150 \mathrm{mg} / 3$ days of Fluconazole was continued for 2 weeks.

\section{Discussion}

During the current pandemic of COVID, numerous manifestations and complications have occurred, including increased risk of fungal infections [8].

Mucormycosis is a fungal infection caused by fungi in the order Mucorales. It has a remarkable high morbidity and mortality, and its incidence is in the ascendant. In healthy individuals, growth of mucor spores is usually resisted by phagocytes, however, in immunocompromised individuals where the host response is compromised, infection exacerbates. The mucor hyphae have an affinity to blood vessels, and invade them, proliferate, and spread within the vessel walls, causing a series of events such as thrombosis, ischemia, necrosis, and finally sequestration of the involved tissue [9].

Mucormycosis occurs after the inhalation of the fungal spores and invasion of the paranasal sinuses, causing necrosis of the nasal mucosa, turbinates, and palate. If untreated or unnoticed, the disease has the ability to spread through the whole face, resulting in facial bone necrosis and penetration of orbits and cranium causing mortality. Osteomyelitis of the maxilla is usually rare due to its rich blood supply and presence of thin cortical plates, however, the high angio-invasiveness potential of mucor fungi affects the endothelial lining of blood vessels, causing vascular insufficiency and bone necrosis resulting in mucormycosis osteomyelitis [10].

Mucormycosis risk factors include immunosuppressive conditions, diabetes mellitus, depilated patients, and leukemia. In our cases, nine patients were diabetics before quarantine, and five patients were not diabetics but showed temporary hyperglycemia after COVID-19 quarantine (cases\#1, 2, 8, 11 and 13). Acidosis and hyperglycemia in diabetic patients lead to suppressed phagocytic capacity of granulocytes, deteriorated antioxidant system, and increased serum free iron, favoring fungal growth and proliferation [11].

Patients with COVID-19 infection may suffer from hypoxia, and during quarantine they can become malnourished and debilitated, resulting in disruption of their immunity [12]. Also, COVID-19 is known to have the ability to cause thromboembolism, which may result in closure of blood vessels, ischemia, and subsequently tissue necrosis [13]. Furthermore, it has been reported that some individuals with COVID-19 develop a diabeteslike syndrome [14].

In Egypt, treatment protocol of COVID-19 contains some drugs that may enhance fungal infection (mucormycosis), such as dexamethasone $1.5 \mathrm{~mL} / 24 \mathrm{~h}$, hydroxychloroquine $400 \mathrm{mg} / 12 \mathrm{~h}$, and broad spectrum antibiotic (cefotax) of $1 \mathrm{gm} / 12 \mathrm{~h}$ during quarantine period. 
In addition to the main effects of corticosteroids as anti-inflammatory and immunosuppressive, steroids can cause drug-induced hyperglycemia. They not only exacerbate hyperglycemia in patients with known diabetes mellitus, but also induce diabetes mellitus in patients without documented hyperglycemia with an incidence that can reach up to $46 \%$ of patients (that can explain post-COVID-19 hyperglycemia in patients with no history of diabetes before quarantine), and increases in glucose levels up to $68 \%$ compared to baseline as they suppress the effectiveness of insulin (insulin resistance) and induce the liver to release stored glucose into the blood stream [15].

Hydroxychloroquine is mainly an anti-inflammatory and immunosuppressive drug used for treatment of malaria, rheumatoid arthritis, and lupus. Therefore, it can decrease patients' immunity and consequently enhance fungal growth [16]. Furthermore, prolonged use of broad-spectrum antibiotics may cause elimination of the competitive influence of the normal bacterial flora resulting in fungal overgrowth [17].

\section{Conclusions}

From this case report we concluded that mucormycosis is a serious condition that can result in high morbidity and mortality, and its incidence is on the rise, particularly in diabetic patients. COVID-19 infection plays a significant role in maxillary mucormycosis osteomyelitis either directly or as a side effect of COVID-19 treatment regimen.

\section{Recommendations}

We recommend careful monitoring of blood glucose level in COVID-19 patients during quarantine. As early diagnosis of these serious conditions is the key to allow for optimum treatment and better outcomes, careful and thorough examination of the oral and maxillofacial area should be done periodically in quarantined patients. Finally, systemic and local antifungal drugs should be prescribed to quarantined COVID-19 patients, particularly in diabetic and immunocompromised patients.

Author Contributions: Conceptualization, W.M.S.A., A.M.E., N.I.R., A.F.A.; methodology, W.M.S.A., A.M.E., N.I.R., A.F.A.; software, W.M.S.A., A.M.E., N.I.R., A.F.A.; validation, W.M.S.A., A.M.E., N.M.E., M.E.-S., N.I.R., A.F.A.; formal analysis, W.M.S.A., A.M.E., N.I.R., A.F.A.; investigation, W.M.S.A., A.M.E., N.M.E., M.E.-S., N.I.R., A.F.A.; writing-original draft preparation, W.M.S.A., A.M.E., N.I.R., A.F.A. writing-review and editing, W.M.S.A., A.M.E., N.M.E., M.E.-S., N.I.R., A.F.A.; supervision; project administration, W.M.S.A. All authors have read and agreed to the published version of the manuscript.

Funding: This research received no external funding.

Institutional Review Board Statement: The study was approved by Ethical Committee of Faculty of Dentistry, Mansoura University No A11010621.

Informed Consent Statement: Written informed consent has been obtained from the patients to publish this paper.

Data Availability Statement: Data are available upon request from the author.

Conflicts of Interest: The authors declared no conflict of interest.

\section{References}

1. Kaye, A.D.; Cornett, E.M.; Brondeel, K.C.; Lerner, Z.I.; Knight, H.E.; Erwin, A.; Charipova, K.; Gress, K.L.; Urits, I.; Urman, R.D.; et al. Biology of COVID-19 and related viruses: Epidemiology, signs, symptoms, diagnosis, and treatment. Best Pract. Res. Clin. Anaesthesiol. 2020, 35, 269-292. [CrossRef] [PubMed]

2. Oran, D.P.; Topol, E.J. The Proportion of SARS-CoV-2 Infections That Are Asymptomatic: A Systematic Review. Ann. Intern. Med. 2021, 174, 655-662. [CrossRef] [PubMed]

3. Raveendran, A.V.; Jayadevan, R.; Sashidharan, S. Long COVID: An overview. Diabetes Metab. Syndr. 2021, 15, 869-875. [CrossRef] [PubMed]

4. Prasad, K.C.; Prasad, S.C.; Mouli, N.; Agarwal, S. Osteomyelitis in the head and neck. Acta Oto-Laryngol. 2007, $127,194-205$. [CrossRef] [PubMed] 
5. Leitner, C.; Hoffmann, J.; Zerfowski, M.; Reinert, S. Mucormycosis: Necrotizing soft tissue lesion of the face. J. Oral Maxillofac. Surg. 2003, 61, 1354-1358. [CrossRef]

6. Yun, S.; Kim, C.; Kwon, T.-G.; Paeng, J.-Y.; Kim, J.; Shin, H.; Choi, S.-Y. Mucormycosis of the Maxilla: A Case Report. Korean J. Oral Maxillofac. Pathol. 2015, 39, 637-642. [CrossRef]

7. Cordeiro, P.G.; Disa, J.J. Challenges in midface reconstruction. In Seminars in Surgical Oncology; John Wiley \& Sons, Inc.: New York, NY, USA, 2000; Volume 19, pp. 218-225. [CrossRef]

8. Werthman-Ehrenreich, A. Mucormycosis with orbital compartment syndrome in a patient with COVID-19. Am. J. Emerg. Med. 2021, 42, 264.e265-264.e268. [CrossRef] [PubMed]

9. Hingad, N.; Kumar, G.; Deshmukh, R. Oral Mucormycosis Causing Necrotizing Lesion in a Diabetic Patient: A Case Report. Int. J. Oral Maxillofac. Pathol. 2012, 3, 8-13.

10. Jones, A.C.; Bentsen, T.Y.; Freedman, P.D. Mucormycosis of the oral cavity. Oral Surg. Oral Med. Oral Pathol. 1993, 75, 455-460. [CrossRef]

11. Ibrahim, A.S. Host cell invasion in mucormycosis: Role of iron. Curr. Opin. Microbiol. 2011, 14, 406-411. [CrossRef] [PubMed]

12. Li, T.; Zhang, Y.; Gong, C.; Wang, J.; Liu, B.; Shi, L.; Duan, J. Prevalence of malnutrition and analysis of related factors in elderly patients with COVID-19 in Wuhan, China. Eur. J. Clin. Nutr. 2020, 74, 871-875. [CrossRef] [PubMed]

13. Zhang, S.; Liu, Y.; Wang, X.; Yang, L.; Li, H.; Wang, Y.; Liu, M.; Zhao, X.; Xie, Y.; Yang, Y.; et al. SARS-CoV-2 binds platelet ACE2 to enhance thrombosis in COVID-19. J. Hematol. Oncol. 2020, 13, 120. [CrossRef] [PubMed]

14. Roberts, J.; Pritchard, A.L.; Treweeke, A.T.; Rossi, A.G.; Brace, N.; Cahill, P.; MacRury, S.M.; Wei, J.; Megson, I.L. Why Is COVID-19 More Severe in Patients With Diabetes? The Role of Angiotensin-Converting Enzyme 2, Endothelial Dysfunction and the Immunoinflammatory System. Front. Cardiovasc. Med. 2020, 7, 629933. [CrossRef] [PubMed]

15. Tamez-Pérez, H.E.; Quintanilla-Flores, D.L.; Rodríguez-Gutiérrez, R.; González-González, J.G.; Tamez-Peña, A.L. Steroid hyperglycemia: Prevalence, early detection and therapeutic recommendations: A narrative review. World J. Diabetes 2015, 6, 1073-1081. [CrossRef] [PubMed]

16. Dos Reis Neto, E.T.; Kakehasi, A.M.; de Medeiros Pinheiro, M.; Ferreira, G.A.; Marques, C.D.L.; da Mota, L.M.H.; Dos Santos Paiva, E.; Pileggi, G.C.S.; Sato, E.I.; Reis, A.; et al. Revisiting hydroxychloroquine and chloroquine for patients with chronic immunity-mediated inflammatory rheumatic diseases. Adv. Rheumatol. 2020, 60, 32. [CrossRef] [PubMed]

17. Azevedo, M.M.; Teixeira-Santos, R.; Silva, A.P.; Cruz, L.; Ricardo, E.; Pina-Vaz, C.; Rodrigues, A.G. The effect of antibacterial and non-antibacterial compounds alone or associated with antifugals upon fungi. Front. Microbiol. 2015, 6, 669. [CrossRef] [PubMed] 